\title{
Innovative Technologies of Cultivation of Crops in the Era of the Digital Economy
}

\author{
N.V. Abramov \\ Doctor of Agricultural Science, Professor \\ Federal State Budgetary Educational \\ Institution of Higher Education \\ «Northern Trans-Ural State Agricultural University» \\ Tyumen, Russia \\ e-mail: vip.anv.55@mail.ru
}

\author{
S. A. Semizorov \\ Candidate of Agricultural Science, Associate Professor \\ Federal State Budgetary Educational \\ Institution of Higher Education \\ «Northern Trans-Ural State Agricultural University» \\ Tyumen, Russia
}

\begin{abstract}
Based on long-term stationary and field experiments (1977-2017), the optimal parameters of soil fertility (gray forest, dark gray forest, leached chernozem) were established. The highest economically and ecologically justified productivity of agrocenoses is obtained when the density of addition for cereals is $1.2 \mathrm{~g} / \mathrm{cm} 3$, the content of productive moisture in the meter layer during the growing season is 120-150 mm or $75 \%$ Field Capacity, the content of agronomically valuable aggregates $(0.25-10 \mathrm{~mm}$ in diameter $)-65-70 \%$, their water resistance $-60-65 \%$, the content of $\mathrm{N}-\mathrm{NO3} 15-20 \mathrm{mg} / \mathrm{kg}$ of soil, $\mathrm{P2O5}, \mathrm{K2O}-20 \mathrm{mg} / \mathrm{kg}$ and the content of humus in the layer 0 $30 \mathrm{~cm}$ is $8-10 \%$.

To archive the rational use of soil fertility, the system of using space systems when performing technological operations of cultivation of agricultural crops is proposed. Digitization of the fields reflected their real configuration and area size, which differed by $10-28 \%$ with the previous maps. Formed agrochemical cartograms for elementary areas of the field and differentiated application of mineral fertilizers in off-line mode stabilized the nutrient regime of leached chernozem. Savings of fertilizers in differentiated application ranged from 14 to $56 \%$, and the profitability of grain production exceeded the traditional (average rate over the entire field) method of fertilizer application by 9-11\%. Parallel movement of the unit across the field reduces reseeding by 10,000 hectares to 550 hectares, reduces overspending of seeds to 130 tons, fertilizers to 80 tons, and fuel to 3850 liters. The inclusion of additional options in accordance with the software in the on-board navigation computer and the technical solution for preserving the rate of fertilizers in additional fertilization at different speed increases the productivity by 2 times or more and ensures the introduction of the estimated dose of mineral fertilizers. Disabling the nozzles when spraying crops with plant protection products in floors, regulating the supply pressure of the spray material, depending on the speed of movement, eliminates the burn of cultivated plants and increases productivity up to $37 \%$.
\end{abstract}

Keywords- innovative technologies, satellite navigation systems, digitization of fields, elementary areas, differentiated application of mineral fertilizers in off - line mode, precision agriculture

\section{INTRODUCTION}

In the era of the digital economy, geographic information systems (GIS) are becoming an integral part of the technological processes of growing crops. Precision agriculture with the use of satellite navigation systems becomes systemic. It should be borne in mind that agrocenosis is a complex biological system, dynamically developing and rapidly changing. The regulation of production processes should be carried out in microperiods of organogenesis and by micro-sites of the field $[1,2,3,4]$

A systematic approach to the implementation of agrotechnologies has been proposed in the process of developing innovative technologies using space systems, starting with the collection of information on agrolandscapes, remote sounding of the Earth and ending with a specific agrotechnique taking into account the heterogeneity of fields and the crops phytosanitary condition. The use of new generation equipment, its compatibility, adaptability to soil and climatic conditions, appropriate selection of chemicalization tools in high technologies help to optimize the resource base of production, to achieve the programmed productivity of agrocenoses with the desired quality of environmentally safe products $[5,6,7,8,9]$.

At the same time, in working environment the attitude towards the main means of production - the soil - remains at the same level. Soil fertility is estimated by average field productivity, which forms a distorted picture of the state of fertility within the field. The result is an ambiguous agroeconomic effect from the implementation of technological measures. Precision agriculture in adaptive landscape systems is the mechanism for the implementation of agronomic laws: the unity of an organism and environment; the cumulative effect of plant life factors; return of fertilizer elements to the soil; minimum, optimum, maximum factors of plant life, etc. The goal of our research is an agroeconomic rationale for performing technological operations of growing crops using space systems.

\section{OBJECTS AND METHODS}

The studies were conducted in long-term stationary experiments in the subtaiga zone, the northern and southern forest steppe of Western Siberia since 1977. The climate of these agro-climatic zones is continental, characterized by long winters and short moderately hot summers. The unobstructed penetration of cold arctic air from the north and dry air from 
Kazakhstan causes sharp changes in the weather and leads to its general instability.

The annual rainfall in the subtaiga zone is 405 , in the northern forest steppe - 374, in the southern forest-steppe - 336 $\mathrm{mm}$, of which, respectively, 240, 232 and 213 falls during the growing season. The sum of temperatures above $+50 \mathrm{C}$ varies between 1850 and 20500, and above $+100 \mathrm{C}-1800-19400$. The period with temperatures above $00 \mathrm{C}$ is 188 in the subtape zone, 194 days in the northern forest steppe, and 197 days in the southern. A steady snow cover is established on November 11, and collapses on April 10, its maximum height is formed in March $31-27 \mathrm{~cm}$, with water reserves in snow of $93 \mathrm{~mm}$. The depth of soil freezing is $113 \mathrm{~cm}$.

This article examines the experimental materials obtained on chernozem, dark gray and gray forest soils. According to L. N. Karetin (1982), chernozems are zonal soils. In the northern forest-steppe, they occupy $17.5 \%$ of the territory, including $37.4 \%$ of arable land. Chernozem soils of the region have a humus horizon thickness of $30-35 \mathrm{~cm}$, the humus content is $6-$ $8 \%$, and its total reserve is $400 \mathrm{t} / \mathrm{ha}$. The granulometric composition of a significant part of chernozem soils is favorable $-35 \%$ medium loam and clay.

Analysis of the soil showed that they have high reserves of nutrients for plants that are in hard-to-reach form and have favorable water-physical properties. The topsoil has a slightly acidic reaction of the environment - the $\mathrm{pH}$ of the aqueous extract is 6.0, the content of nitrogen according to Kedal in the layer of $0-30 \mathrm{~cm}-0.42-0.39 \%$.

Dark gray forest soils have a humus horizon of $26 \mathrm{~cm}$, the structure is lumpy-silty, by granulometric composition - loamy, the amount of $\mathrm{CaCO} 3$ in the humus horizon is within $4.5-7.5 \%$, the humus content is $6 \%$.

The state of soil fertility and the ways of its regulation were carried out according to generally accepted (determined by GOST) methods in 12 crop rotations at different levels of chemicalization and various systems of basic, preplant soil tillage.

\section{RESULTS AND DISCUSSIONS}

At the first stage of the innovative technologies development, the potential of agro-ecosystems was determined. It showed the potential productivity of the main crops cultivated in Western Siberia. Practically, this means what the commodity producer should strive for, using the technologies of the new generation, taking into account economic and environmental expediency.

The first level factor which determines the potential productivity of crops is photosynthetically active radiation (PAR), a part of solar energy that can be used by plants. Using the formula: $\mathrm{y}_{\text {bio }}=\frac{Q_{P A R^{*}} \mathrm{~K}_{P A R}}{100 \mathrm{~g}}$ where

$\mathrm{y}_{\text {bio }}$ - biological yield, $\mathrm{t} / \mathrm{ha}$;

$Q_{P A R}$ - solar radiation arrival during the growing season of the crop, GJ / ha;

$\mathrm{K}_{P A R}$ - utilization ratio of $\mathrm{PAR}, \%$ $g$ is the caloric value of a unit of yield, GJ / c.

Calculation of potential productivity of agricultural crops is made. For example, the potential grain yield of spring wheat in the conditions of the northern forest steppe of Western Siberia is $13.74 \mathrm{t} / \mathrm{ha}$.

Currently, farmers of the Tyumen region set the task to obtain an average grain yield of $2.5 \mathrm{t} / \mathrm{ha}$, which is only $18.2 \%$ of the agrocenosis' potential productivity.

In obtaining the possible yield of agricultural crops in the forest-steppe zone of Western Siberia, the moisture supply often becomes a limiting factor. In the years with good and even precipitation, favorable temperature conditions during the growing season after the predecessors of the first group, when productive moisture resources were $697 \mathrm{~mm}$, and the water consumption ratio was $8.5 \mathrm{~mm} / \mathrm{t}$, the calculated yield of spring wheat with accurate agrotechnical measures reached $8.20 \mathrm{t} / \mathrm{ha}$

In the process of managing productivity, the amplitude of the variability of the intensity and duration of exposure to a plant environmental factor is important. Productivity is taken as the main criterion for agro-ecotype adaptability. In Western Siberia conditions, thermal resources are the limiting factor of the third level of formation of high productivity of agrocenoses. They are in close relationships with the radiation and water balance of agricultural landscapes. Calculations of the possible yield of spring wheat for thermal resources in the northern forest-steppe with favorable bio-thermal conditions are $8.38 \mathrm{t}$ / ha.

The second stage in transition to innovative technologies is the establishment of optimal parameters of soil fertility needed to obtain the maximum possible economically and environmentally sound crop yield. Based on years of research there has been developed a soil fertility model that provides cultivated plants with the best conditions for growth and development: Thus, the highest productivity of spring wheat of $5.96 \mathrm{t} / \mathrm{ha}$ was obtained at a density of addition of leached chernozem $1.18-1.22 \mathrm{~g} / \mathrm{cm}^{3}$ in the layer $0-30 \mathrm{~cm}$, the content of agronomically valuable aggregates $(0.25-10 \mathrm{~mm}$ in diameter) - $65-70 \%$, their water resistance $60-65 \%$, the content of N-NO3$15-20 \mathrm{mg} / \mathrm{kg}$ of soil, P2O5, K2O- 250 - $260 \mathrm{mg} / \mathrm{kg}$, humus $8-10 \%$, productive moisture content during the growing season in a meter layer $120-150 \mathrm{~mm}$ or $74 \%$ of $\mathrm{HB}$; at a $\mathrm{pH}$ of the arable layer of $6.2-6.8$.

The use of the mathematical modeling method made it possible to streamline the acquisition of these results in the field of the «soil - plant - space factors», and to investigate most deeply and comprehensively the dependence of the productivity of agrocenoses on soil fertility parameters. The model presents the relationship between soil fertility factors and the yield of spring wheat, which is expressed mathematically by the following function:

$$
\begin{aligned}
& \mathrm{y}=-2.59+0.47 x_{1}^{27.4} \exp \left(-3.2 x_{1}^{4}\right) x_{2}{ }^{0.75} \exp \left(-0.005 x_{2}\right) \\
& x_{3}^{0.16} x_{4}^{0.07} x_{5}{ }^{0.05} x_{6}{ }^{0.06}+1,48 \exp \left(-0.003 x_{7}\right)+0.82 \exp \left(-0.01 x_{8}\right)
\end{aligned}
$$

where $\mathrm{y}$ is the yield of spring wheat, $\mathrm{t} / \mathrm{ha}$;

$$
x_{1} \text { - soil density, } \mathrm{g} / \mathrm{cm}^{3} \text {; }
$$


$x_{2}$ - reserves of productive moisture in the meter layer, mm;

$x_{3}$ - water-resistant structure, $\%$;

$x_{4}$ - nitrate nitrogen, $\mathrm{mg} / \mathrm{kg}$ of soil;

$x_{5}$ - mobile phosphorus, $\mathrm{mg} / \mathrm{kg}$ of soil;

$x_{6}$ - exchangeable potassium, $\mathrm{mg} / \mathrm{kg}$ of soil;

$x_{7}$ - air dry weight of weeds, $\mathrm{g} / \mathrm{m}^{2} ; x_{8}$ - root rot, $\% ; R^{2}-$ coefficient of determination; $\mathrm{S}$ is the standard deviation of the model.

According to this model, it is possible to predict the yield of spring wheat depending on the condition of crops (weediness, root rot), soil fertility, as well as intervals of increase or decrease in yield depending on changes in the values of leached chernozem fertility factors [11].

Thus, the highest yield of spring wheat of $5.87 \mathrm{t} / \mathrm{ha}$ is achieved with a minimum amount of weeds and root rot, with a maximum content in the soil of water-resistant aggregates $(75 \%)$ of nitrate nitrogen $(20 \mathrm{mg} / \mathrm{kg})$, mobile phosphorus $(250$ $\mathrm{mg} / \mathrm{kg}$ ), exchangeable potassium $(260 \mathrm{mg} / \mathrm{kg})$, when the density of the soil and the reserves of productive moisture are, respectively, $1.21 \mathrm{~g} / \mathrm{cm}^{3}$ and $150 \mathrm{~mm}$, which corresponds to their optimal combination.

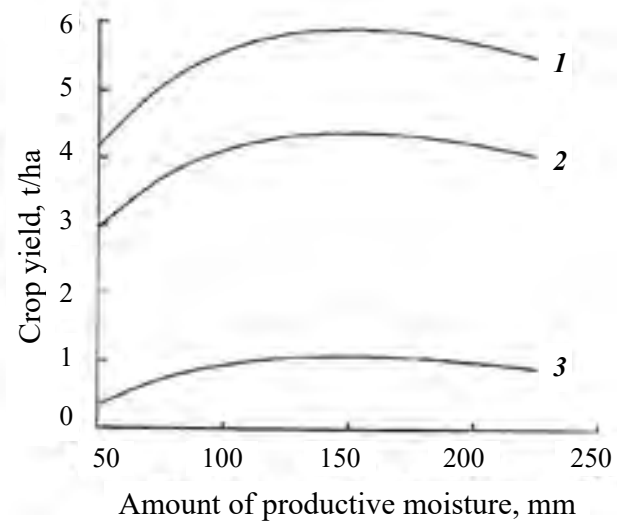

Fig. 1. Crop yield of spring wheat depending on the amount of productive moisture with: 1 - Optimal level of fertility factors; 2 - Levels of the most frequent factors: 3 - Levels of factors that gave the lowest crop yield.

Soil fertility regulation is provided by a scientifically based system of crop rotation and tillage with the organo-mineral fertilizer system. We have proposed an economic and mathematical optimization of the structure of acreage, which ensures the highest possible economically and environmentally sound crop yields while maintaining soil fertility [12].

$$
z=\sum b_{j i k}, x_{i k} \rightarrow \max , i \in N_{1}, i \in N_{2}
$$

where $N_{1}$ is cultivated crops, $N_{2}$ are the crop rotations and their links, $b_{j i k}$ - yield of the $j$-th species per unit area, i-th crop, k-th crop rotation or link.

A large information base of cosmic and terrestrial factors for the production of agrocenoses is the basis for optimizing the production processes of precision agriculture. Geo-information systems make it possible to control the production of agroecosystems not only on average across the region, zones and even the field, but over the inner-field elementary sections.

However, the practical use of geographic information systems in technological operations of cultivation of crops also requires a certain sequence. The primary task is to develop a methodology for creating electronic plans of farm fields, because in previously created maps, for several reasons, there are differences in their areas, configuration and concentration of on-farm facilities, including forests within the boundaries of each field. As a result, farms are forced to update and form their own field plans. The most accurate, but also time-consuming method of solving the problem is considered to be a combined one, which consists of forming the tracks of the geographic coordinate reference of the boundaries of each individual field when detouring with the onboard navigation complex and recording the boundaries on a satellite image of a given area using a geodetic program. Practice has shown that, using the example of the second branch of the Educational and Experimental Economy of our university, the difference in the smaller area of fields was 100.6 hectares, out of $1,340.7$ hectares declared on the old map. The largest concurrence in area in one field of the 29 analyzed was noted with a difference of 0.3 hectares, and the smallest - of 14.8 hectares. With farms updated field plans in electronic form, you can make rotations, design a digital model of field relief on electronic media, field history books, debris maps, a tillage system, more accurately carry out calculations of seed, fuel, chemicals etc.

The second task was to create a methodology for monitoring the fertility of agricultural land. Based on the developed electronic field plans in the geodesic program or in the Google Earth program, each field is marked up into elementary areas with an average area of 20 hectares, which are loaded into the BNC "Agronavigator". Then, using a soil sampler (of our own production) on a mobile complex, guided by a circuit map in an agronavigator, $15-20$ soil samples in a $0-40 \mathrm{~cm}$ layer are taken from each elementary site, which are mixed into a combined sample.

The data of the agrochemical survey of the soil provide the possibility of differentiated application of fertilizers in elementary areas in the off-line mode using satellite navigation systems. The effectiveness of this technology of applying nitrogen fertilizers when sowing spring wheat increased in the fields when the content of N-N in the soil was varied from weak to high availability of cultivated plants and spatial heterogeneity from 16.3 to $36 \%$. When feeding winter crops, perennial grasses, you can use the on-board navigation computer (BNC) software to perform additional functions. At the same time, technologically parallel driving of the unit, differential fertilizer application in elementary areas and automatic regulation of the rate of fertilizer application regardless of the unit movement speed are solved here. 
Similar functions are performed when the sprayers operate in plant protection. Software and technical solution here additionally gives the opportunity to turn off the sprayer nozzles in the overlap. Manufacturers are interested in the use of satellite navigation systems in mapping fields by yield, monitoring the quality of sowing, fuel consumption, etc.
Elements of precision agriculture ensure the rational use of the natural soil fertility and the means of chemicalization in planning yields of 3-4 t / ha. The parallel movement of the unit across the field reduces costs by 10 thousand hectares for seeds by 780 thousand rubles, for fertilizers by 736 thousand, for fuel - by 91 thousand rubles.

TABLE I. PERFORMANCE INDICATORS OF THE SOWING COMPLEX "HORSCH" WITH A NAVIGATOR

\begin{tabular}{|c|c|c|c|c|c|c|c|c|}
\hline \multirow{2}{*}{ Aspects } & \multicolumn{2}{|c|}{ Without a navigator } & \multicolumn{2}{|c|}{ With a navigator } & \multicolumn{2}{|c|}{ The difference } & \multicolumn{2}{|c|}{ Efficiency, rub. } \\
\hline & On 1 ha & On 10000 ha & On 1 ha & On $10000 \mathrm{ha}$ & On 1 ha & On $10000 \mathrm{ha}$ & On 1 ha & On $10000 \mathrm{ha}$ \\
\hline Re-seeding area & $778.4 \mathrm{~m}^{2}$ & 780 ha & $227.3 \mathrm{~m}^{2}$ & 230 ha & $551.1 \mathrm{~m}^{2}$ & 550 ha & - & - \\
\hline Seed overrun & $19 \mathrm{~kg}$ & $190 \mathrm{t}$ & $6 \mathrm{~kg}$ & $60 \mathrm{t}$ & $13 \mathrm{~kg}$ & $130 \mathrm{t}$ & 780 & 780000 \\
\hline Fertilizer overrun & $12 \mathrm{~kg}$ & $120 \mathrm{t}$ & $4 \mathrm{~kg}$ & $40 \mathrm{t}$ & $8 \mathrm{~kg}$ & $80 \mathrm{t}$ & 74.4 & 736000 \\
\hline Fuel overconsumption & 0.5461 & 54601 & 0.1611 & 16101 & 0.3851 & 38501 & 9.163 & 91630 \\
\hline
\end{tabular}

The greatest success of the application of innovative technologies is archieved when they are used in the complex. In the Tyumen region, elements of precision farming are used in $34 \%$ of farms, but they are fragmented. The most systematic acquired technology using space systems are in Instructional farm of State Agricultural University Northern Zauralye on an area of 3454 hectares, JSC "Priozernoe" Yalutorovskiy district on an area of 2,671 hectares, and in the Sverdlovsk region SEC Kalininsky - on an area of 7455 hectares
The use of a satellite navigation system, starting from digitizing fields and performing technological operations, has allowed us to increase arable land productivity dynamically over the course of 4 years. So for 4 years in Uchkhoz GAU of Northern Zaura grain yield increased from 30.5 to 37.8 centners per hectare, OJSC Priozernoe from 28.0 to 39.0 cwt. per hectare. At the same time, the profitability of grain production increased by 15 and $24 \%$, while the cost of 1 cwt. grain decreased by 118 and 140 rubles, respectively.

TABLE II. GRAIN YIELD AND PROFITABILITY OF FARMS USING INNOVATIVE CULTIVATION TECHNOLOGIES

\begin{tabular}{|c|c|c|c|c|c|}
\hline Farm & Aspects & $\mathbf{2 0 1 4}$ & $\mathbf{2 0 1 5}$ & $\mathbf{2 0 1 6}$ & $\mathbf{2 0 1 7}$ \\
\hline Instructional farm SAU Northern Zauralye & Yield, cwt/ha & 30.5 & 34.2 & 31.9 & 37.8 \\
\cline { 2 - 6 } & Prime cost, rub./cwt & 685 & 659 & 595 & 567 \\
\cline { 2 - 6 } & Profitability, \% & 71 & 127 & 74 & 86 \\
\hline \multirow{2}{*}{ JSC "Priozernoe" } & Yield, cwt/ha & 28 & 30 & 30 & 39 \\
\cline { 2 - 6 } & Prime cost, rub./cwt & 679 & 698 & 583 & 539 \\
\cline { 2 - 6 } & Profitability, \% & 0 & 9 & 8 & 24 \\
\hline
\end{tabular}

Thus, geographic information systems are of an essential nature for the transition to innovative technologies of agricultural crops cultivation using space systems. The elements of the PA (Precision Agriculture) ensure the rational use of the natural soil fertility and the means of chemicalization in planning the yield of cereals 3-4 $\mathrm{t} / \mathrm{ha}$.

The movement of the unit across the field using navigation equipment reduces costs (in terms of 100 hectares): for seeds by $1,200.2$ thousand rubles; fertilizers -756 thousand rubles; on the fuel - $71.4 \mathrm{rub}$.
The use of the developed method of differentiated mineral fertilizers in the off-line mode, depending on the content of batteries in elementary areas, reduces the application rate, relative to the traditional method, by $14-56 \%$ and provides savings of $3.72-3.96$ million rubles per 10.000 ha.

Precision agriculture eliminates the negative effect of selfsuppression of plants at the junctions of the pass of sowing aggregates, ensures the uniformity of the elements of the crop structure, the simultaneous development of plants and the ripening of the crop. 


\section{References}

[1] V.P. Yakushev, V.V. Yakushev, Informational support for precision agriculture. St. Petersburg, 2007, p.382

[2] I.M. Mikhaylenko, Management of precision agriculture systems. St. Petersburg, 2005, p. 233

[3] R.A. Afanasyev, Agrochemical principles of precision agriculture. Geoinformational technologies in agriculture, Orenburg, 2013. pp. 3-7.

[4] N.V. Abramov, Productivity of agroecositse and soil fertility in conditions of Western Siberia, Tyumen, 2013, p. 270

[5] C. Bahr, O. Kaufmann, K. Schebe Tagungsband, Kiathos, Greece, Wageningen, Niederland, 2007 Wageningen Academics Publishers. [3rd European Conference on Precise Livestock Farming, p. 269, 2007]

[6] J. Bontsema, K. Van Asselt, T. Groot, "Intra row weed control”, Bornimer Agrartechnische Berichte, vol. 31, 2002, pp. 64-72.
[7] K.-H. Dammer, G. Wartenberg, "Sensor-based weed detection and application of variable", Crop Protection, vol. 26, 2007, pp. 270-277.

[8] M. Demmel, “Automatische Spurfuhrung von Landmaschinen- Systeme, Einsatzbereiche, Wirtschaftlichkeit, Lanawirtschaftliche Schriftenreihe, vol. 21, 2006, pp. 19-30 [Tagungsband der Landtechnischen Jahrestagung am ,Deggendorf. Bayerische Landesanstalt fur Landwirtschaft (Hrsg.), 23 November 2006]

[9] D. Ehlert, V. Hammen, R. Adamek, "On-line sensor pendulum meter", Precision Agriculture, vol. 4, 2003, pp. 139-148.

[10] N.V. Abramov, S.A. Semizorov, S.V. Sherstobitov, "Farming using space systems", Farming, vol. 5, 2012, pp.12-19.

[11] N.V. Abramov, E.V. Salova, "The optimum parameters determing the fertility of leached chernozem in the northern part of the forest- steppe zone in west Siberia", Eurasian soil science, 1998, No. 10, pp. 1131-1136.

[12] N.V. Abramov, G.P. Selyukova, Optimization of the structure of acreage on a bioenergy basis, Yekaterinburg, URGA, 2001, p. 144 